\title{
Analisis Kebutuhan Pengembangan Petunjuk Praktikum Fisiologi Tumbuhan untuk Pembelajaran Jarak Jauh
}

\author{
Rahmadyah Kusuma Putri \\ E-mail: rahmadyahkusumaputri@ fkip.upr.ac.id \\ Fakultas Keguruan dan Ilmu Pendidikan Universitas Palangka Raya \\ Jalan Yos Sudarso, Palangka Raya, Kalimantan Tengah 73111
}

No. Tlp/WA: 085263252885

\begin{abstract}
Abstrak
Petunjuk praktikum merupakan pedoman untuk melaksanakan praktikum agar sesuai dengan teori dan tujuan. Desain praktikum jarak jauh selama pandemi perlu mempertimbangkan ketersediaan alat bahan dan kemudahan untuk dilaksanakan secara mandiri. Oleh sebab itu, petunjuk praktikum juga perlu disesuaikan dengan alat bahan, serta prosedur yang lebih sederhana. Penelitian ini bertujuan menggambarkan analisis kebutuhan petunjuk praktikum Fisiologi Tumbuhan untuk pembelajaran jarak jauh. Data dikumpulkan dengan instrumen kuisioner dan wawancara. Kuisioner diberikan kepada mahasiswa program studi Pendidikan Biologi Universitas Palangka Raya semester VI kelas A 2020/2021 ( $n=27)$. Wawancara dilakukan kepada dosen pengampu mata kuliah Fisiologi Tumbuhan Program Studi Pendidikan Biologi Universitas Palangka Raya. Hasil kuisioner analisis kebutuhan menunjukkan bahwa: 1) Pembelajaran daring membosankan karena metode belajar monoton (51\%), 2) Pembelajaran daring sulit dipahami karena media pembelajaran tidak representatif terhadap materi (62\%), 3) Pembelajaran daring sulit dipahami karena tidak ada buku referensi, diktat ataupun bahan ajar pendukung lainnya yang sesuai dengan materi dalam RPS (62\%), 4) Umumnya praktikum daring tidak dapat dilaksanakan karena membutuhkan laboratorium $(66 \%), 5)$ Praktikum daring membosankan karena menggunakan metode belajar yang monoton $(55 \%), 6)$ Ada materi Fisiologi Tumbuhan yang sulit dipahami $(81 \%)$, 7) Mata kuliah Fisiologi Tumbuhan membutuhkan praktikum untuk membuktikan teori $(96 \%), 8)$ Bahan ajar format digital dan multimedia lebih mudah digunakan untuk pembelajaran daring jarak jauh (96\%), 9) Bahan ajar format digital dan multimedia lebih menarik digunakan untuk pembelajaran daring jarak jauh (100\%), dan 10) Diperlukan pedoman praktikum bentuk digital untuk mata kuliah Fisiologi Tumbuhan (100\%). Hasil wawancara analisis kebutuhan menyimpulkan bahwa belum tersedia petunjuk praktikum yang menggunakan alat, bahan, dan prosedur yang sederhana. Petunjuk praktikum yang tersedia hanya dapat dilaksanakan di dalam laboratorium. Dengan demikian, disimpulkan bahwa diperlukan pengembangan petunjuk praktikum Fisiologi Tumbuhan untuk pembelajaran jarak jauh dalam format $e$-book multimedia.
\end{abstract}

Kata Kunci : Daring, Fisiologi Tumbuhan, Pembelajaran Jarak Jauh, Petunjuk Praktikum 


\section{Pendahuluan}

Pandemi Covid-19 menyebabkan penyesuaian berbagai strategi mengajar jarak jauh di Perguruan Tinggi di Indonesia. Pembelajaran jarak jauh melibatkan teknologi sebagai media dalam proses pembelajaran. Media tersebut dapat bersifat synchronous yang memungkinkan interaksi dan pertukaran informasi antara dosen dan mahasiswa secara langsung atau Asynchronous yang hanya memungkinkan interaksi antara mahasiswa dan materi pembelajaran (Moallem, 2015). Dalam praktiknya, media synchronous seperti video conference zoom, whatsapp, dan LMS (Learning Media System) memberikan peluang bagi mahasiswa untuk berkolaborasi antar-mahasiswa maupun dosen secara realtime. Sementara itu, media asynchronous memberikan fasilitas untuk mahasiswa dalam belajar mandiri. Kedua media ini menjadi pilihan dalam pelaksanaan proses pembelajaran.

Kelas teori, umumnya menggunakan media yang bersifat synchronous, yaitu melalui video conference, baik zoom, webex, google meeting, dan LMS Universitas. Media tersebut sangat mendukung kegiatan kelas teori secara daring selama pandemi yang membutuhkan interaksi realtime saat berdiskusi, sehingga tujuan pembelajaran dapat dicapai dengan maksimal (Pakpahan \& Fitriani, 2020). Media synchronous juga mampu meningkatkan minat mahasiswa dalam mengikuti mata kuliah karena lebih interaktif dan efektif (Brahma, 2020).

Sementara itu, dalam struktur kurikulum Program Studi Pendidikan Biologi Universitas Palangka Raya mewajibkan adanya praktikum sebagai pendukung untuk kelas teori mata kuliah keilmuan dan keterampilan (MKK). Praktikum merupakan bagian dari standar proses dalam standar nasional pendidikan tinggi yang bertujuan untuk memberikan keterampilan saintifik pada mahasiswa. Artinya, meskipun pandemi, praktikum tetap diadakan secara jarak jauh. Menurut survey online yang dilakukan (Hikmat et al., 2020), diketahui bahwa media synchronous kurang efektif untuk kelas praktikum. Strategi pembelajaran praktikum selama pandemi yang paling umum adalah dengan tutorial yang diunggah melalui youtube (Halawa, 2021). Strategi tersebut memanfaatkan media asynchronous berupa video pembelajaran. Praktikum dapat berjalan efektif apabila alat dan bahan dapat disediakan oleh mahasiswa secara mandiri. Hal yang sama juga diungkapkan pada penelitian Maulana \& Hamidi (2020), yaitu terdapat kendala dalam pelaksanaan mata kuliah praktik karena keterbatasan kemampuan mahasiswa dalam menyediakan perangkat yang dibutuhkan.

Pada mata kuliah praktikum Fisiologi Tumbuhan, umumnya diperlukan alat laboratorium. Sebagai contoh, mahasiswa membutuhkan mikroskop untuk praktikum pengamatan difusi dan osmosis yang terjadi pada sel tumbuhan. Mahasiswa membutuhkan flux meter dalam praktikum pengamatan pengaruh cahaya terhadap fotosintesis. Mahasiswa membutuhkan PH meter tanah dan alat ukur NPK tanah pada praktikum kandungan zat hara tanah. Mahasiswa tentu kesulitan menyediakan alat tersebut. Oleh karena itu, dibutuhkan penyederhanaan desain praktikum. Selanjutnya, agar praktikum dapat berjalan sesuai dengan konsep dan tujuan, maka mahasiswa perlu dibekali dengan petunjuk praktikum. Petunjuk praktikum merupakan pedoman untuk melaksanakan praktikum. Desain praktikum jarak jauh 
selama pandemi perlu mempertimbangkan ketersediaan alat bahan dan kemudahan untuk dilaksanakan secara mandiri.

Dengan demikian, penelitian analisis kebutuhan perlu dilakukan untuk mengetahui kebutuhan pengembangan petunjuk praktikum Fisiologi Tumbuhan untuk pembelajaran jarak jauh dan bagaimana format petunjuk praktikum yang dibutuhkan mahasiswa.

\section{Metode}

Penelitian ini dilakukan di Program Studi Pendidikan Biologi Universitas Palangka Raya pada bulan Maret sampai dengan April 2021. Subjek penelitian adalah mahasiswa semester VI ( $n=27)$ dan dosen pengampu mata kuliah Fisiologi Tumbuhan $(n=1)$ di program studi Pendidikan Biologi Universitas Palangka Raya.

Penelitian ini merupakan bagian dari tahap Analyze dari model pengembangan ADDIE. Adapun tahap ADDIE secara lengkap terdiri dari Analyze, Design, Development, Implementation dan Evaluation (Branch, 2009). Tahap analyze bertujuan untuk mengidentifikasi masalah dan menganalisis solusi yang dapat diterapkan. Prosedur pada tahap ini adalah: 1) validate the performance gap (memvalidasi kesejangan kinerja), 2) determine instructional goals (menentukan tujuan instruksional), 3) analyze learners (menganalisis pembelajar), 4) audit available resources (mengaudit sumber yang tersedia), 5) recommend potential delivery systems (merekomendasikan bentuk bahan ajar yang potensial) dan compose a project management plan (merencanakan manajemen proyek pengembangan).

Instrumen penelitian yang digunakan adalah kuisioner dan lembar wawancara. Kuisioner terdiri dari 10 pertanyaan yang bertujuan untuk menganalisis kebutuhan pedoman praktikum untuk pembelajaran jarak jauh dan diajukan kepada subjek penelitian, yaitu mahasiswa. Lembar wawancara terdiri dari 10 pertanyaan yang bertujuan untuk menganalisis ketersediaan pedoman praktikum dan kebutuhan pengembangan pedoman praktikum untuk pembelajaran jarak jauh. Wawancara dilakukan kepada dosen pengampu mata kuliah Fisiologi Tumbuhan yang sudah mengajar lebih dari dua puluh tahun di program studi Pendidikan Biologi Universitas Palangka Raya. Hasil penelitian dianalisis secara deskriptif untuk mengetahui kebutuhan pengembangan pedoman praktikum untuk pembelajaran jarak jauh. Data ditampilkan dalam bentuk tabel.

\section{Hasil dan Pembahasan}

Analisis kebutuhan dilaksanakan sesuai dengan prosedur tahap Analyze dari model ADDIE.

1. Validate the performance gap (memvalidasi kesejangan kinerja). 
Prosedur validate the performance gap (memvalidasi kesejangan kinerja) merupakan prosedur untuk menemukan masalah melalui kuisioner dan wawancara. Analisis hasil kuisioner yang diberikan pada mahasiswa menunjukkan beberapa fakta (Tabel 1).

Tabel 1. Hasil Kuisioner Analisis Kebutuhan

\begin{tabular}{|c|c|}
\hline Pertanyaan & $\begin{array}{c}\text { Setuju } \\
(\%)\end{array}$ \\
\hline Pembelajaran daring membosankan karena metode belajar monoton (sama) & 51 \\
\hline $\begin{array}{l}\text { Pembelajaran daring sulit dipahami karena media pembelajaran kurang mendukung } \\
\text { (representatif terhadap materi) }\end{array}$ & 62 \\
\hline $\begin{array}{l}\text { Pembelajaran daring sulit dipahami karena tidak ada buku referensi, diktat ataupun } \\
\text { bahan ajar pendukung lainnya yang sesuai dengan materi dalam RPS }\end{array}$ & 62 \\
\hline $\begin{array}{l}\text { Umumnya praktikum daring tidak dapat dilaksanakan karena membutuhkan } \\
\text { laboratorium }\end{array}$ & 66 \\
\hline $\begin{array}{l}\text { Praktikum daring membosankan karena menggunakan metode belajar yang monoton } \\
\text { (sama) }\end{array}$ & 55 \\
\hline Ada materi Fisiologi Tumbuhan yang sulit dipahami & 81 \\
\hline Mata kuliah Fisiologi Tumbuhan membutuhkan praktikum untuk membuktikan teori & 96 \\
\hline $\begin{array}{l}\text { Bahan ajar format digital dan multimedia lebih mudah digunakan untuk pembelajaran } \\
\text { daring jarak jauh }\end{array}$ & 96 \\
\hline $\begin{array}{l}\text { Bahan ajar format digital dan multimedia lebih menarik digunakan untuk pembelajaran } \\
\text { daring jarak jauh }\end{array}$ & 100 \\
\hline Diperlukan pedoman praktikum bentuk digital untuk mata kuliah Fisiologi Tumbuhan & 100 \\
\hline
\end{tabular}

Hasil kuisioner menunjukkan bahwa mahasiswa berpendapat pembelajaran daring membosankan karena metode belajar yang monoton. Mahasiswa sulit memahami materi tanpa media yang mendukung dan bahan ajar yang sesuai dengan materi di RPS. Selain itu, praktikum mata kuliah Fisiologi Tumbuhan diperlukan sebagai penunjang untuk materi yang sulit dipahami. Namun, mahasiswa berpendapat bahwa umumnya praktikum tidak dapat dilaksanakan tanpa laboratorium. Oleh karena itu, dibutuhkan petunjuk praktikum dengan alat bahan dan prosedur yang sederhana agar mahasiswa dapat melaksanakan praktikum secara mandiri tanpa laboratorium. Format pedoman praktikum yang lebih menarik bagi mahasiswa adalah format digital.

Kesimpulan yang sama diperoleh dari hasil wawancara dengan dosen pengampu mata kuliah Fisiologi Tumbuhan di program studi Pendidikan Biologi Universitas Palangka Raya. Berdasarkan hasil 
wawancara diperoleh bahwa selama lebih dari dua puluh tahun mengajar di program studi Pendidikan Biologi, praktikum Fisiologi Tumbuhan selalu dilaksanakan di laboratorium dengan bantuan alat laboratorium. Pedoman praktikum tersedia sebagai penuntun mahasiswa dalam melaksanakan praktikum. Selama pandemi, praktikum dilaksanakan secara sederhana dan hanya pada topik yang mudah, seperti pengamatan peristiwa difusi dan osmosis menggunakan kentang dan larutan gula. Namun, untuk praktikum yang membutuhkan pengamatan sel menggunakan mikroskop, maka mahasiswa secara terbatas mengadakan praktikum di laboratorium kampus. Hal tersebut membutuhkan waktu yang panjang dan tidak memberikan pengalaman yang sama pada setiap mahasiswa (ada mahasiswa yang tidak dapat hadir). Oleh karena itu diperlukan alternatif praktikum yang sederhana dan dapat dilakukan mandiri, namun tetap sesuai dengan konsep materi Fisiologi Tumbuhan. Berdasarkan hasil kuisioner dan wawancara, maka diketahui bahwa dibutuhkan pengembangan pedoman praktikum Fisiologi Tumbuhan untuk pembelajaran jarak jauh.

\section{2) Determine instructional goals (menentukan tujuan instruksional)}

Prosedur Determine instructional goals (menentukan tujuan instruksional) merupakan prosedur untuk menjabarkan tujuan pengembangan bahan ajar sebagai solusi atas masalah yang ditemukan. Perumusan tujuan didasarkan pada hasil prosedur Validate the performance gap (memvalidasi kesejangan kinerja). Adapun tujuan pengembangan pedoman praktikum Fisiologi Tumbuhan untuk pembelajaran jarak jauh adalah: 1) mendukung pembelajaran Fisiologi Tumbuhan secara jarak jauh dengan adanya praktikum jarak jauh, 2) menyusun pedoman praktikum dengan format digital yang menarik bagi mahasiswa, 3) menyusun pedoman praktikum dengan alat bahan dan prosedur yang sederhana sesuai dengan konsep materi Fisiologi Tumbuhan.

\section{3) Analyze learners (menganalisis pembelajar)}

Prosedur Analyze learners merupakan prosedur untuk mengidentifikasi karakteristik umum mahasiswa, jumlah mahasiswa, lokasi mahasiswa, pengalaman belajar, pengetahuan awal dan keterampilan yang berdampak pada kesuksesan pembelajaran. Hasil dari prosedur ini, diketahui bahwa: mahasiswa yang menjadi sampel penelitian berjumlah 27 orang. Umumnya mahasiswa berasal dari provinsi Kalimantan Tengah dan satu orang berasal dari Sumatera Utara. Mahasiswa memiliki fasilitas belajar daring seperti laptop dan smatrphone. Mahasiswa yang mengikuti mata kuliah praktikum Fisiologi Tumbuhan adalah mahasiswa semester VI yang telah lulus mata kuliah prasyarat seperti anatomi tumbuhan dan botani tumbuhan tingkat tinggi. Kompetensi awal mahasiswa dinilai sudah memenuhi syarat untuk dapat melaksanakan praktikum pada mata kuliah Fisiologi Tumbuhan.

4) Audit available resources (mengaudit sumber yang tersedia) merupakan prosedur untuk mengidentifikasi ketersediaan bahan ajar yang mendukung pembelajaran terkait dengan masalah yang 
ditemukan pada prosedur sebelumnya. Bahan ajar yang tersedia sebagai pendukung kegiatan praktikum Fisiologi Tumbuhan adalah video pembelajaran yang disiapkan oleh mahasiswa pada mata kuliah Fisiologi Tumbuhan dan buku Fisiologi Tumbuhan yang digunakan sebagai rujukan, diantaranya Plant Physiology. $4^{\text {th }}$ ed. oleh Sallisbury dan Ross dan Introduction to plant physiology 4 th ed oleh Hopkins.

5) Recommend potential delivery systems (merekomendasikan bentuk bahan ajar yang potensial). Recommend potential delivery systems merupakan prosedur untuk menjabarkan solusi pengembangan bahan ajar yang dapat dilakukan terkait masalah. Prosedur ini menghasilkan keputusan jenis bahan ajar yang akan dikembangkan. Berdasarkan hasil prosedur 1 sampai 4, maka dapat disimpulkan bahwa petunjuk praktikum yang akan dikembangkan sebaiknya berformat digital dan dapat diakses secara daring oleh mahasiswa. Adapun bentuk petunjuk praktikum yang akan dikembangkan adalah e-book multimedia, yaitu buku berbentuk digital yang dilengkapi dengan video prosedur praktikum.

6) Compose a project management plan (merencanakan manajemen proyek pengembangan) merupakan prosedur untuk menyusun langkah-langkah pengembangan multimedia e-book petunjuk praktikum. Langkah - langkah yang akan dilakukan dalam pengembangan multimedia $e$-book petunjuk praktikum adalah: 1) merangkum materi Fisiologi Tumbuhan, 2) merancang alat bahan dan prosedur praktikum, 3) membuat video prosedur praktikum dan 4) menyusun materi dan video kedalam e-book multimedia petunjuk praktikum.

Berdasarkan hasil analisis kebutuhan, diketahui bahwa mahasiswa semester VI yang mengikuti mata kuliah praktikum Fisiologi Tumbuhan membutuhkan praktikum yang mampu menjelaskan konsep penting untuk materi yang sulit pada mata kuliah Fisiologi Tumbuhan. Namun, praktikum tidak dapat dilakukan di laboratorium kampus karena kebijakan pembatasan aktivitas akademik di kampus selama pandemi. Oleh karena itu, mahasiswa diharapkan menyediakan alat bahan secara mandiri. Upaya dalam mendukung pelaksanaan praktikum Fisiologi Tumbuhan tersebut, adalah dengan mengembangkan petunjuk praktikum dalam format $e$-book multimedia. Bahan pembelajaran berbasis digital, seperti $e$ book sudah banyak dikembangkan dan digunakan di berbagai Perguruan Tinggi di Indonesia.

Penelitian pengembangan e-book interaktif untuk mata kuliah pengembangan multimedia pembelajaran interaktif oleh Mawarni \& Muhtadi (2017), menunjukkan bahwa mahasiswa mampu memahami konsep dan mengaplikasikan konsep tersebut untuk menghasilkan produk. Hal ini membuktikan bahwa e-book, sebagai media pembelajaran mampu memberikan panduan atau pedoman bagi pembacanya untuk melaksanakan suatu prosedur. Oleh karena itu, pengembangan $e$-book petunjuk praktikum Fisiologi Tumbuhan juga diharapkan dapat memandu mahasiswa dalam melaksanakan praktikum Fisiologi Tumbuhan dengan baik. 
Pengembangan e-book yang dilakukan Sari (2016) pada mata kuliah Cookies and Candys, mengungkapkan bahwa e-book dapat mendukung mahasiswa untuk belajar tanpa batasan ruang dan waktu, artinya dapat diakses melalui smartphone kapanpun. Begitupula dalam pengembangan e-book multimedia pedoman praktikum Fisiologi Tumbuhan, ditujukan agar mahasiswa dapat melakukan praktikum dengan mudah dimana pun dan kapan pun. Selain itu, (Aswin dkk., 2018) melalui pengembangan $e$-book berbasis penelitian potensi lokal untuk mata kuliah Ekologi, memaparkan bahwa materi dalam e-book dapat bersifat kontekstual dan lokal, sehingga mendukung pembelajaran yang autentik untuk mahasiswa. Penerapannya dalam pengembangan $e$-book multimedia petunjuk praktikum Fisiologi Tumbuhan adalah menggunakan alat dan bahan yang bersifat lokal atau dapat diperoleh dengan mudah di sekitar lokasi mahasiswa. Dengan demikian, diharapkan petunjuk praktikum dapat menuntun mahasiswa dalam praktikum Fisiologi Tumbuhan. Sehingga setiap mahasiswa program studi Pendidikan Biologi Universitas Palangka Raya memperoleh pengalaman saintifik berkaitan dengan teori Fisiologi Tumbuhan.

\section{Kesimpulan}

Hasil kuisioner analisis kebutuhan menunjukkan bahwa: 1) Pembelajaran daring membosankan karena metode belajar monoton $(51 \%)$, 2) Pembelajaran daring sulit dipahami karena media pembelajaran tidak representatif terhadap materi (62\%), 3) Pembelajaran daring sulit dipahami karena tidak ada buku referensi, diktat ataupun bahan ajar pendukung lainnya yang sesuai dengan materi dalam RPS (62\%), 4) Umumnya praktikum daring tidak dapat dilaksanakan karena membutuhkan laboratorium (66\%), 5) Praktikum daring membosankan karena menggunakan metode belajar yang monoton (55\%), 6) Ada materi Fisiologi Tumbuhan yang sulit dipahami (81\%), 7) Mata kuliah Fisiologi Tumbuhan membutuhkan praktikum untuk membuktikan teori (96\%), 8) Bahan ajar format digital dan multimedia lebih mudah digunakan untuk pembelajaran daring jarak jauh (96\%), 9) Bahan ajar format digital dan multimedia lebih menarik digunakan untuk pembelajaran daring jarak jauh (100\%) dan 10) Diperlukan pedoman praktikum bentuk digital untuk mata kuliah Fisiologi Tumbuhan (100\%). Hasil wawancara analisis kebutuhan menyimpulkan bahwa belum tersedia petunjuk praktikum yang menggunakan alat bahan dan prosedur yang sederhana. Dengan demikian, disimpulkan bahwa diperlukan pengembangan petunjuk praktikum Fisiologi Tumbuhan dalam bentuk e-book multimedia untuk pembelajaran jarak jauh.

\section{References}

Aswin, P., Irawati, M. H., \& Saptasari, M. (2018). Persepsi Mahasiswa Biologi Terhadap Pengembangan Ebook Berbasis Penelitian Potensi Lokal Untuk Matakuliah Ekologi Program Studi Pendidikan Biologi Universitas Bengkulu. Prosiding Semnas Pendidikan Biologi (ISBN: 978-602-61265-2-8), Juni 2018, 137-140. 
Brahma, I. A. (2020). Penggunaan Zoom Sebagai Pembelajaran Berbasis Online dalam Mata Kuliah Sosiologi dan Antropologi pada Mahasiswa PPKN di STKIP Kusumanegara Jakarta. Aksara: Jurnal Ilmu Pendidikan Nonformal, 6(2), 97-102.Https://Doi.Org/10.37905/Aksara.6.2.97-102.2020

Branch, R. . (2009). Instructional Design: The Addie Approach. New York: Springer.

Halawa, M. V. B. (2021). Efektivitas Pemanfaatan Platform Media Sosial Dalam Pembelajaran Praktikum Secara Daring. Attractive:Innovative Education Journal, 3(1), 52-64.

Hikmat, Hermawan, E., Aldim, \& Irwandi. (2020). Efektivitas Pembalajaran Daring Selama Masa Pandemi Covid-19: Sebuah Survey Online. In Digital Library, Uin Sunan Gung Djati, Bandung. Http://Digilib.Uinsgd.Ac.Id/30625/

Maulana, H. A., \& Hamidi, M. (2020). Persepsi Mahasiswa Terhadap Pembelajaran Daring pada Mata Kuliah Praktik di Pendidikan Vokasi. Equilibrium: Jurnal Pendidikan, 8(2), 224-231.

Mawarni, S., \& Muhtadi, A. (2017). Pengembangan Digital Book Interaktif Mata Kuliah Pengembangan Multimedia Pembelajaran Interaktif Untuk Mahasiswa Teknologi Pendidikan. Jurnal Inovasi Teknologi Pendidikan, 4(1), 84-96.

Moallem, M. (2015). The Impact Of Synchronous And Asynchronous Communication Tools On Learner Self-Regulation, Social Presence, Immediacy, Intimacy And Satisfaction In Collaborative Online Learning. The Online Journal Of Distance Education And E-Learning, 3(3), 55-77.

Pakpahan, R., \& Fitriani, Y. (2020). Analisa Pemafaatan Teknologi Informasi dalam Pemeblajaran Jarak Jauh Di Tengah Pandemi Virus Corona Covid-19. Jisamar (Journal Of Information System, Applied, Management, Accounting And Researh), 4(2), 30-36.

Sari, A. S. (2016). The Development Of Digital Book Through Sigil Application In Cookies Dan Candys Lessons. Jurnal Science Tech, 1(2), 46-54. 